\title{
Platelet Aggregation After Strict Metabolic Control Using the Artificial Pancreas
}

Dear Sir,

There is an increasing body of evidence to suggest that patients with diabetes mellitus have accelerated atherosclerotic vascular disease which seems primarily dependent on endothelial injury [1]. An increased sensitivity to platelet aggregating agents has been demonstrated in the majority of diabetic patients with established large and small vessel disease [2]. The biochemical events associated with the increased platelet sensitivity could be explained by an accelerated release of arachidonic acid from platelet membranes [3]. However, there is at present no substantial evidence to determine whether platelet hyperactivity is a cause or consequence of the small vessel complications of diabetes; neither is it clear whether platelet hyperactivity is an early event in diabetes or is secondary to the metabolic derangements of the disease.

We have investigated the role of strict metabolic control achieved with the aid of the artificial pancreas (Biostator, Miles, Cavenago Brianza, Italy) on platelet function. Ten diabetic patients (six females and four males) participated in the study (group 1). They were all insulin-dependent, age 15-50 years (mean 37 years) with a duration of known disease from 1 to 15 years (mean 10 years). Platelet function was assessed by determining platelet aggregation response to ADP (end concentration $1.25 \mu \mathrm{mol} / \mathrm{l}$ ) according to Born [4] and circulating platelet aggregates according to $\mathrm{Wu}$ and Hoak [5]. The results for circulating platelet aggregates are expressed as a ratio (platelet count ratio): this ratio approaches 1 in the absence of significant amounts of aggregates and drops below 1 when aggregates are present. The mean coefficient of varation of platelet count ratio measurements within samples is $\pm 8 \%$.

Table 1. Blood glucose concentrations, platelet aggregation response to ADP and platelet count ratio in insulin-dependent diabetic patients submitted to the artificial pancreas

\begin{tabular}{|c|c|c|c|c|c|}
\hline & \multicolumn{3}{|c|}{$\begin{array}{l}\text { Group } 1(n=10) \\
\text { (feed-back) }\end{array}$} & \multicolumn{2}{|c|}{$\begin{array}{l}\text { Group } 2(n=8) \\
\text { (monitoring) }\end{array}$} \\
\hline & Before & $p$ & After & Before & After \\
\hline $\begin{array}{l}\text { Glucose } \\
(\mathrm{mmol} / \mathrm{l})\end{array}$ & $\begin{array}{r}13.3 \pm \\
1.7\end{array}$ & $<0.001$ & $\begin{array}{l}5.1 \pm \\
0.2\end{array}$ & $\begin{array}{r}14.3 \pm \\
1.9\end{array}$ & $\begin{array}{r}12.2 \pm \\
2.1\end{array}$ \\
\hline $\operatorname{ADP}(\%)$ & $\begin{array}{r}43.2 \pm \\
3.6\end{array}$ & $<0.01$ & $\begin{array}{r}35.9 \pm \\
2.7\end{array}$ & $\begin{array}{r}42.1 \\
3.5\end{array}$ & $\begin{array}{r}43.7 \\
3.2\end{array}$ \\
\hline $\begin{array}{l}\text { Platelet count } \\
\text { ratio }\end{array}$ & $\begin{array}{l}0.71 \pm \\
0.05\end{array}$ & $<0.001$ & $\begin{array}{l}0.93 \pm \\
0.08\end{array}$ & $\begin{array}{l}0.74 \pm \\
0.05\end{array}$ & $\begin{array}{l}0.82 \pm \\
0.06\end{array}$ \\
\hline
\end{tabular}

Results are expressed as mean \pm SEM
Table 1 shows that $24 \mathrm{~h}$ of strict metabolic control caused a complete normalization of blood glucose, a significant reduction of the aggregation response to $\operatorname{ADP}(p<0.01)$ and the disappearance of circulating platelet aggregates which were present in the basal state. Our results confirm the presence in human diabetes of platelet hyperactivity and demonstrate that these abnormal responses are reversed by strict metabolic control. The significance of these findings is strengthened by the lack of significant variation of platelet aggregation and platelet aggregates in a matched-group of diabetic patients whose glycaemic profile was only monitored during the study period (group 2 Table 1) and by the recent findings of Juhan et al. [6] who observed a significant reduction of platelet hyperactivity in insulin-dependent diabetic patients after a similar period of strict metabolic control. It therefore seems likely that platelet hyperactivity is a consequence of the metabolic derangements of diabetes mellitus.

Yours sincerely,

D. Giugliano, L. Misso, A. Tirelli, L.Coppola, P. Di Pinto and R. Torella

\section{References}

1. Steiner G (1981) Diabetes and atherosclerosis. An overview. Diabetes 30 (Suppl 2): 1-7

2. Colwell JA, Lopes-Virella M, Alushka PV (1981) Pathogenesis of atherosclerosis in diabetes mellitus. Diabetes Care 4: 121-133

3. Halushka PV, Lurie D, Colwell JA (1977) Increased synthesis of prostaglandin-E like material by platelets from patients with diabetes mellitus. N Engl J Med 297: 1306-1310

4. Born CVR (1962) Aggregation of blood platelet by adenosinediphosphate and its reversal. Nature 194: 927-929

5. Wu KK, Hoak JC (1974) A new method for the quantitative detection of platelet aggregates in patients with arterial insufficiency. Lancet 2: 924-929

6. Juhan I, Buonocore M, Jouve R, Vague Ph, Moulin JP, Vialettes B (1982) Abnormalities of erythrocyte deformability and platelet aggregation in insulin-dependent diabetics corrected by insulin in vivo and in vitro. Lancet 1: $535-538$

Dr. D. Giugliano

Institute of Medical Pathology

I Faculty of Medicine

University of Naples

80138 Naples, Italy

\section{Book Reviews}

Publishers are asked not to send copies of books for review unless specifically requested but to enquire with the editors first. They will then order a copy if appropriate for the journal. We cannot guarantee the return of unrequested review copies received.

D.S.Schade, R. P. Eaton, K. G. M. M. Alberti and D. G. Johnston: Diabetic Coma: Ketoacidotic and Hyperosmolar. University of New Mexico Press, December 1981. pp 250. Hardback US \$ 29.95

This is a book that could save lives, and so must be approved. Patients would benefit if their doctor had learnt about diabetic hyperglycaemic coma from so informative and extensively referenced a book, though these very virtues may make it more difficult for nurses and paramedical personnel to extract what they need from it (the single author preface claims them as its target just as much as the physicians). However, all will rapidly benefit from close study of the third portion, duplicated within the front and back covers, but not reaching the table of contents, though the preface reckons it the most important in content. 